\title{
PEMBINAAN AKHLAK SISWA MELALUI METODE PEMBIASAAN DI MI WAHID HASYIM YOGYAKARTA
}

Anna Khoirunisa, Nur Hidayat

\author{
Mahasiswa Doktoral Prodi Psikologi Pendidikan Islam \\ Universitas Muhammadiyah Yogyakarta \\ Email:bos_hidayat@yahoo.com
}

\begin{abstract}
ABSTRAK
Zaman modern ini, anak-anak sejak dini harus mendapatkan perhatian lebih serius. Terutama dalam pendidikan akhlak, agar mereka tidak menjadi anak-anak yang lemah iman sehingga dapat tumbuh dewasa menjadi generasi yang sholih dan sholihah. Permasalahan yang diangkat dalam artikel ini adalah bagaimana proses perencanaan pembinaan akhlak siswa dan bagaimana implementasi metode pembiasaan dalam pembinaan akhlak siswa tersebut. Penelitian ini bertujuan untuk mengetahui sejauh mana proses pembinaan akhlak terpuji siswa melalui metode pembiasaan.

Permasalahan yang dikaji dalam penelitian ini adalah: (1) bagaimana proses perencanaan pembinaan akhlak siswa melalui metode pembiasaan di MI Wahid Hasyim Yogyakarta, (2) bagaimana implementasi pembinaan akhlak siswa melalui metode pembiasaan di MI Wahid Hasyim Yogyakarta, (3) apa faktor-faktor yang menjadi kendala dalam pembinaan akhlak siswa melalui metode pembiasaan di MI Wahid Hasyim Yogyakarta. Jenis penelitian ini merupakan penelitian kualitatif dengan mengambil lokasi di MI Wahid Hasyim Yogyakarta. Pengumpulan data dilakukan dengan mengadakan pengamatan, wawancara dan dokumentasi. Analisis data dilakukan dengan memberikan makna terhadap data yang berhasil dikumpulkan, dan dapat ditarik kesimpulan.
\end{abstract}

\section{Kata Kunci: Akhlak, Metode Pembiasaan}

\begin{abstract}
This modern age, children from early on should get more serious attention. Especially in moral education, so that they do not become children who are weak in faith so they can grow up to become a generation who sholih and sholihah. The issues raised in this article is how the process of planning the morals of students and how the implementation of methods of habituation in the guidance of morals students. This study aims to determine the extent to which the process of fostering morality students through the method of habituation habituation.
\end{abstract}

The problems studied in this research are: (1) how the process of planning of morals of

AL-BIDAYAH: Jurnal Pendidikan Dasar Islam

Volume 9, Nomor 02, Desember 2017; ISSN: 2085-0034 
students through the method of habitation in MI Wahid Hasyim Yogyakarta, (2) how the implementation of moral coaching students through the method of habitation in MI Wahid Hasyim Yogyakarta, (3) what factors which become obstacles in the moral development of students through the method of habitation in MI Wahid Hasyim Yogyakarta. This type of research is a qualitative research by taking the location in MI Wahid Hasyim Yogyakarta. Data collection is done by conducting observations, interviews and documentation. Data analysis is done by giving meaning to the data collected, and can be drawn conclusion.

\section{Keywords: Moral, Habituation Method}

\section{PENDAHULUAN}

Akhlak mempunyai pengaruh yang besar terhadap kehidupan pribadi setiap manusia di suatu bangsa. Dalam syair dikatakan: "Sesungguhnya bangsa itu tetap hidup selama bangsa itu berakhlak, jika akhlak mereka lenyap maka hancurlah mereka". ${ }^{101}$ Nabi Muhammad SAW adalah seorang Rasul yang diutus pada saat terjadi kebobrokan akhlak. Allah SWT mengutus Nabi Muhammad SAW untuk menyempurnakan akhlak yang terpuji. Sebagaimana hadits Nabi SAW yang diriwayatkan oleh Imam Ahmad, Rasulullah SAW bersabda:

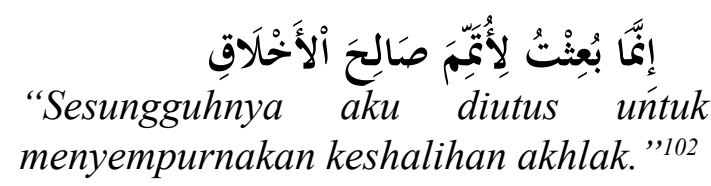

Ajaran-ajaran akhlak Rasulullah adalah ajaran yang terkandung dalam Al-Qur'an, yang di dalamnya mengajarkan bagaimana moral individu manusia terhadap kehidupan sosial dan kehidupan agamanya. Secara garis besar, mengajarkan tentang tata cara bagaimana

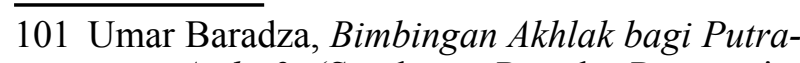
putri Anda-2, (Surabaya: Pustaka Progressip, 1992), hlm. 1.

102 Zuhairini, Filsafat Pendidikan Islam, (Jakarta: Bumi Aksara, 1992), hlm.50. seharusnya hidup di dunia, dan menjelaskan bagaimana seharusnya perilaku manusia. Yaitu, dalam berpikir, merasa, dan bertindak, baik untuk dirinya yang sesuai dengan petunjuk Allah SWT. Manusia dilahirkan dalam keadaan suci dan bersih. Pada dasarnya manusia mempunyai potensi untuk menerima kebaikan atau keburukan. Hal ini dijelaskan Allah, sebagai berikut.

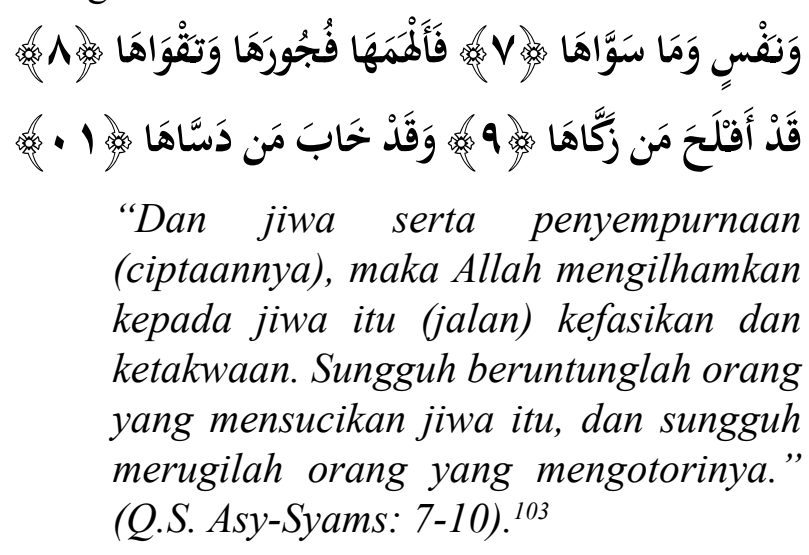

Ayat tersebut mengindikasikan bahwa manusia mempunyai kesempatan yang sama untuk membentuk akhlaknya. Apakah dengan pembiasaan yang baik atau dengan pembiasaan yang buruk. Pembiasaan yang dilakukan sejak dini akan membawa kegemaran dan kebiasaan sehingga menjadi bagian yang tidak

103 Departemen Agama RI, Al-Qur'an dan Terjemahannya, (Semarang, CV Toha Putra, 1989), hlm. 1064. 
terpisahkan dari kepribadian manusia. AlGhazali mengatakan: ${ }^{104}$

"Anak adalah amanah orang tuanya, hatinya yang bersih adalah permata berharga dan murni, yang kosong dari setiap tulisan dan gambar. Hati ini siap menerima tulisan dan cenderung pada setiap yang ia inginkan. Oleh karena itu, jika dibiasakan mengerjakan yang baik, lalu tumbuh di atas kabaikan itu maka bahagialah ia di dunia dan akhirat, orang tuanya pun mendapat pahala bersama".

Orang tua hendaknya waspada terhadap ancaman arus globalisasi yang akan menggerus kepribadian anak. Menurut Zakiah Daradjat, bahwa salah satu timbulnya krisis akhlak yang terjadi dalam masyarakat adalah karena lemahnya pengawasan sehingga respon terhadap agama kurang. ${ }^{105}$ Krisis akhlak tersebut mengindikasikan tentang kualitas pendidikan agama yang seharusnya memberi nilai spiritual namun justru tidak memiliki kekuatan karena kesadaran dalam beragama kurang.

Melihat begitu pentingnya pendidikan agama, maka upaya pembinaan akhlak merupakan salah satu usaha yang diharapkan dapat membentuk kepribadian muslim yang berbudi luhur, saleh dan salehah. Dalam rangka membentuk kepribadian tersebut tidak hanya memberikan pengetahuan tentang mana yang baik dan salah, melainkan harus disertai dengan pembinaan-pembinaan. Tujuannya, agar siswa dapat mengetahui secara jelas apa yang diperintahkan dan apa yang dilarang dalam ajaran Islam. Kemudian, dapat

104 Muhammad Rabbi Muhammad Jauhari, Akhlaquna, terjemahan. Dadang Sobar Ali, (Bandung: Pustaka Setia, 2006), hlm. 109.

105 Zakiah Daradjat, Peranan Agama dalam Kesehatan Mental, (Jakarta: Gunung Agung, 1982), hlm. 72. merealisasikannya dalam kehidupan sehari-hari secara ikhlas tanpa paksaan. Pembinaan akhlak ini terasa semakin diperlukan terutama pada saat manusia di zaman modern ini. Dihadapkan pada masalah moral dan akhlak yang cukup serius, jikalau dibiarkan akan menghancurkan masa depan bangsa. Seperti realita sekarang ini yang banyak ditemukan di beberapa media massa. Praktik hidup yang menyimpang seperti korupsi, penodongan, perampokan, pembunuhan, pemerkosaan ,dan perampasan hak asasi manusia.

Zaman modern ini semakin banyak tantangan dan godaan. Hal ini, sebagai dampak dari kemajuan di bidang Ilmu Pengetahuan dan Teknologi (IPTEK). Dampak dari kemajuan IPTEK tersebut menawarkan berbagai kemudahan dan kenyamanan hidup. Di samping itu, juga membuka peluang untuk melakukan kejahatan lebih canggih lagi jika ilmu pengetahuan dan teknologi tersebut disalahgunakan.

Berdasarkan observasi yang peneliti lakukan di MI Wahid Hasyim Yogyakarta sejak 11 Januari 2017 sampai dengan 11 April 2017, peneliti menemukan ada proses pembiasaan bagi siswa. Adapun metode pembiasaan yang diterapkan di antaranya adalah mengucapkan salam, senyum dan sapa, bersalaman saat bertemu guru, serta pembiasaan disiplin dalam menjalankan program Sholat Dhuha dan Sholat Dhuhur berjamaah. Kemudian, pembiasaan membaca dan menghafal surat-surat AlQur'an dan berinfak. Selain itu juga terdapat pembiasaan menjaga kebersihan lingkungan, dan pembiasaan tolong-menolong sesama warga madrasah.

Ternyata ada perbedaan perilaku bagi siswa dalam menjalankan pembiasaan disiplin yang diterapkan di madrasah. Kemudian, ada 
perubahan dalam pergaulan yang menjadikan suasana lingkungan madrasah lebih islami. Selain itu diterapkan juga pembiasaan kepedulian sosial yang ditekankan pada siswa. Yaitu, dalam hal saling menolong, dalam kebaikan. Seperti meminjami teman yang lupa membawa alat tulis, menjenguk teman yang sedang sakit, takziyah ke keluarga teman yang meninggal, dan infak rutin yang dilaksanakan seluruh siswa setiap hari Jum'at. ${ }^{106}$

Keberhasilan pembinaan akhlak juga dipengaruhi oleh faktor kerjasama dari pihak madrasah (sebagai tempat anak belajar yang sifatnya formal) dengan pondok pesantren. Karena adanya beberapa pendidik di madrasah ini yang juga tinggal di Pondok Pesantren Wahid Hasyim sehingga dapat membantu terwujudnya pembinaan akhlak bagi siswa. Masing-masing dari pendidik kebanyakan masih berstatus sebagai mahasiswa. Jadi, konsentrasi dalam mendidik, membimbing dan mengawasi siswa tidak dapat dilaksanakan secara penuh karena harus dibagi dengan kebutuhan kuliah. Dengan adanya kerjasama tersebut diharapkan dapat saling membantu dan melengkapi satu sama lain. Sehingga tugas dan tanggung jawab sebagai pendidik dapat terpenuhi.

Dalam penerapan metode pembiaasaan tersebut masih terdapat beberapa siswa yang tidak mengikuti kegiatan pembiasaan. Sebagaimana ditetapkan oleh pihak madrasah untuk meningkatkan kualitas akhlak dari setiap siswanya. Penyimpangan-penyimpangan yang dilakukan itu di antaranya siswa tidak mengikuti pembiasaan ibadah sholat Dhuha, dan sholat Dhuhur secara berjamaah, serta kegiatan membaca dan menghafal surat-surat Al-Qur'an. Selain itu peneliti juga menemukan

106 Hasil observasi pada hari Sabtu, 27 Agustus 2016 di MI Wahid Hasyim Yogyakarta adanya siswa yang mengucapkan kata-kata kotor dan jorok ketika berbicara, membuang sampah sembarangan, dan membolos. Kemudian, masih dijumpai siswa yang kurang menghormati gurunya. Padahal letak MI Wahid Hasyim Yogyakarta ini berada satu lingkup dengan Pondok Pesantren Wahid Hasyim Yogyakarta yang masih berada dalam lingkungan yang islami.

Adanya pondok pesantren sebagai tempat mencari ilmu keagamaan merupakan salah satu solusi yang efektif yaitu, untuk mengatasi kondisi pertumbuhan kepribadian seorang anak. Selain itu, pondok pesantren juga merupakan lembaga pendidikan yang di dalamnya diciptakan suasana agamis. Kemudian, dibudayakan pembiasaan berperilaku yang didasarkan pada agama melalui kehidupan di lingkungan pondok pesantren tersebut. Bahkan ada beberapa siswa MI Wahid Hasyim Yogyakarta ini yang tinggal di pondok tersebut. Mereka seringkali melanggar aturan-aturan yang telah ditetapkan oleh pihak madrasah.

\section{METODE PENELITIAN}

Metode penelitian ini adalah penelitian kualitatif. Metode yang digunakan dalam penelitian ini merupakan studi kasus. Di sini, peneliti berusaha untuk mengetahui bagaimana pembinaan akhlak terpuji siswa melalui metode pembiasaan di MI Wahid Hasyim Yogyakarta. Metode yang digunakan adalah observasi, metode wawancara, dan terakhir, metode dokumentasi.

\section{HASILPENELITIAN DAN PEMBAHASAN}

Perencanaan merupakan proses penetapan tujuan dan penentuan apa yang harus dikerjakan untuk merealisasikannya. Perencanaan ini 
berkaitan dengan menciptakan prosedur, aturan dan pedoman untuk mencapai tujuan organisasi. Secara operasional perencanaan dapat diartikan sebagai suatu proses penentuan dan penyusunan program-program yang akan dilaksanakan dan ditentukan sebagai program kegiatan.

Dengan perencanaan penerapan program kegiatan dapat lebih terarah dan mengenai pada sasaran yang diinginkan secara lebih terarah dan teratur secara rapi. Selain itu perencanaan memungkinkan dipilihnya tindakan-tindakan yang tepat sesuai dengan situasi dan kondisi yang ada di MI Wahid Hasyim Yogyakarta. Sebab perencanaan mendorong para pimpinan dan segenap para pengurus untuk terlebih dahulu memperkirakan dan memperhitungkan secara matang mengenai berbagai hal yang akan terjadi berdasarkan hasil pengamatan dan menganalisa terhadap situasi dan kondisi.

Dalam hal ini perencanaan implementasi pembinaan akhlak siswa melalui metode pembiasaan tentu memiliki beberapa hal yang melatarbelakanginya. Adapun terkait latar belakang diadakannya program penerapan tersebut adalah:

Dari tahun 2004 kita mulai menggunakan Kurikulum Pesantren. Nah dari sini kita bisa mengadakan program-program pembiasaan seperti yang telah Mbak Anna ketahui. Karena kita mengusung 4 visi ya, salah satu di antaranya yaitu penanaman akhlakul karimah, tapi kalau lengkapnya ada pengembangan bahasa, program pengembangan tahfidzul Qur'an, pengembangan minat dan bakat. Dari penanaman akhlakul karimah itu kita jabarkan menjadi satu program pembiasaan melalui kegiatan sehari-hari. Ya contohnya seperti sholat Dhuha dan sholat Dhuhur, tahfidz, BTAQ, dan sebagainya. Nanti bisa juga di lihat di dokumen kami, mbak. ${ }^{107}$

Darihasilwawancaradiatas dapat diketahui, bahwa terbentuknya pembinaan akhlak dengan menggunakan metode pembiasaan yakni sejak tahun 2004. Di sini, bahwa MI Wahid Hasyim mulai menggunakan Kurikulum Pesantren. Implementasi pembinaan akhlak melalui metode pembiasaan dilatarbelakangi oleh tuntutan kebutuhan atau target yang harus dicapai. Oleh karena itu, pihak madrasah berusaha membina para siswanya agar sejak dari bangun tidur hingga akan tidur lagi melaksanakan kegiatankegiatan yang baik dan bermanfaaat. Bahkan beberapa siswa madrasah ini tinggal di asrama Pondok Pesantren Wahid Hasyim. Maka dari itu, pihak madrasah juga menjalin kerjasama dengan pihak pengelola pondok.

Setiap kegiatan yang akan dilaksanakan tentunya memiliki tujuan, begitu pula dengan diterapkannya pembinaan akhlak terpuji melalui metode pembiasaan. Tujuan utama dari implementasi tersebut adalah mencetak generasi yang berakhlakul karimah sejak dini. Kemudian, meningkatkan mutu siswa dan madrasah, dan dapat unggul di bidang akademik maupun non akademik. Hal ini berdasarkan wawancara yang peneliti lakukan dengan kepala madrasah, sebagai berikut:

Anak usia dini ini sangat mudah terpengaruh dengan lingkungannya. Maka sebaik mungkin kita menciptakan lingkungan yang baik untuk tumbuh kembangnya siswa tersebut. Melalui kegiatan-kegiatan yang kita programkan, kita dapat membentengi para siswa dengan akhlak yang baik. Sehingga

107 Hasil wawancara dengan Bapak Aris Munandar, S.H.I,. M.Pd.I selaku kepala madrasah MI Wahid Hasyim Yogyakarta pada hari Kamis, 19 Januari 2017 pukul 09.05 WIB 
siswa tahu jika nanti dalam kehidupan bermasyarakat dapat membedakan mana hal yang positif dan mana yang negatif. Selain itu untuk meningkatkan mutu siswa itu sendiri dan juga madrasah serta kita sebaik mungkin juga dapat membina para siswa tidak hanya dalam bidang akademiknya saja, akan tetapi dalam bidang non akademik juga. ${ }^{108}$

Metode pembiasaan dalam pembinaan akhlak siswa yang diterapkan MI Wahid Hasyim Yogyakarta berdasarkan persetujuan dari Yayasan Pondok Pesantren Wahid Hasyim, yaitu bahwa pembiasaan berjabat tangan dan salam, membaca doa sebelum dan sesudah kegiatan belajar mengajar, membaca sholawat, kegiatan BTAQ dan tahfidz. Kemudian, pelaksanaan sholat Dhuha dan sholat Dhuhur berjamaah, dan kegiatan berinfak. Jadi, para siswa di madrasah ini sejak dini diajarkan melalui pendekatan keagamaan, yaitu melalui kegiatan beribadah dan mengenal Al-Qur'an. Sehingga jika dewasa nanti, para siswa sudah tahu dan akan dengan sendirinya menjalankan kebiasaan-kebiasaan baik yang pernah diajarkan oleh pihak madrasah.

Dalam rangka mencapai target visi dan misi MI Wahid Hasyim Yogyakarta, sholat Dhuha dan sholat Dhuhur diterapkan bagi seluruh siswanya menjadi salah satu pembiasaan oleh pihak madrasah. Hal yang melatarbelakangi diadakannya pembiasaan ini karena saat usia dini siswa akan cenderung melakukan hal-hal yang berpengaruh pada lingkungan sekitarnya. Selain itu pada siang hari atau pada waktu Dhuhur siswa masih melaksanakan kegiatan belajar mengajar di madrasah. Jadi pihak

108 Hasil wawancara dengan Bapak Aris Munandar, S.H.I.. M.Pd.I selaku kepala madrasah MI Wahid Hasyim Yogyakarta pada hari Kamis, 19 Januari 2017 pukul 09.05 WIB madrasah mengajak para siswanya untuk senantiasa menjalankan sholat lima waktu, terutama pada saat siswa masih berada di madrasah yaitu pada waktu Dhuhur.

Tujuan penerapan pembiasaan ini menurut wawancara terhadap koordinator sholat, sebagai berikut:

Kami berusaha memberikan pembinaan akhlak yang baik untuk para siswa. Salah satunya dengan kegiatan beribadah ini yaitu sholat. Tujuannya ya agar siswa terbiasa dan senantiasa menjalankan perintah Allah salah satunya sholat. Yang mana jika nanti mereka berada di rumah atau di manapun, mereka tidak akan lupa dengan sholat, apalagi sholat lima waktu. Dimana siswa akan terbiasa menjalankannya tanpa disuruh oleh orang di sekitarnya. ${ }^{109}$

Praktiknya, sholat Dhuha dan sholat Dhuhur berjamaah ini belum sepenuhnya berjalan dengan baik. Karena belum adanya bentuk jadwal imam dan muadzin yang terbentuk. Selain itu jadwal sholat masih berubah-ubah seiring jadwal pelajaran yang belum pasti. Kegiatan BTAQ dan tahfidz yang diterapkan oleh pihak madrasah merupakan program unggulan. Seperti yang dikatakan oleh kepala madrasah, sebagai berikut :

Kegiatan BTAQ dan tahfidz ini merupakan program unggulan di madrasah kita, karena kegiatan ini juga mengacu pada Kurikulum Pesantren yang juga merupakan salah satu kurikulum yang diterapkan di sini. ${ }^{110}$

109 Hasil wawancara dengan Bapak Deni Endika Suteja selaku koordinator sholat di MI Wahid Hasyim Yogyakarta pada hari Kamis, 19 Januari 2017 pukul 10.30 WIB

110 Hasil wawancara dengan Bapak Aris Munandar, S.H.I,. M.Pd.I selaku kepala madrasah MI Wahid Hasyim Yogyakarta pada hari Kamis, 19 Januari 2017 pukul 09.05 WIB 
Hal ini juga sejalan dengan wawancara peneliti dengan koordinator BTAQ dan tahfidz, sebagai berikut:

Kegiatan ini menjadi unggulan di madrasah karena mencetak para generasi penghafal Al-Qur'an. Jadi kalau sejak dini di sini sudah mulai menghafal itu akan membantu mereka nantinya. Diharapkan dengan diadakannya program BTAQ dan tahfidz ini madrasah mampu bersaing dengan yang lainnya dan mempunyai nilai lebih khususnya di bidang agama. ${ }^{111}$

Demi tercapainya tujuan tersebut, maka MI Wahid Hasyim Yogyakarta menargetkan para siswanya agar mampu membaca dan mengahafalkan Al-Qur'an. Bagi kelas I target pencapaian meliputi An-naas, Al-falaq, Alikhlas, Al-lahab, An-nashr, Al-kafirun, Alma'un, Al-quraisy, Al-fiil, Al-humazah, Alashr. Target pencapaian kelas II meliputi Attakatsur, Al-qori'ah, Al-adiyat, Al-zalzalah, Albayinah, Al-qadr, Al-alaq, At-tin, Al-insyiroh, Adh-dhuha. Target pencapaian kelas III meliputi Al-lail, Asy-syams, Al-balad, Al-fajr, Al-ghasyiyah, Al-a'la, Ath-thariq, Al-buruj, Alinsyiqaq. Target pencapaian kelas IV meliputi Al-muthofifin, Al-infitar, At-takwir, 'Abasa, An-nazi'at, An-naba'. Target pencapaian kelas V meliputi Juz 1 (Al-baqarah ayat 1-76). Dan target pencapaian kelas VI meliputi Juz 1 (Albaqarah ayat 77-141). ${ }^{112}$

Selain itu, pihak madrasah juga membentuk kelas tahfidz khusus. Kelas tahfidz khusus merupakan suatu wadah untuk menyaring para siswa yang mempunyai kemampuan menghafal

111 Hasil wawancara dengan Ibu Hikmah Maslahah, selaku koordinator 1 BTAQ dan tahfidz MI Wahid Hasyim Yogyakarta pada hari Kamis, 9 Maret 2017 pukul 10.15 WIB

112 Hasil dokumentasi MI Wahid Hasyim Yogyakarta lebih cepat dari siswa pada umumnya. Kelas ini dibuka untuk siswa yang duduk di kelas II sampai dengan kelas V. Sebelum masuk kelas tahfidz khusus, siswa dites terlebih dahulu kemampuan membaca (binnadzri) dan hafalan (bilhifdzi) serta persetujuan dari wali murid terkait izin mengikuti kelas tahfidz khusus. Kelas tahfidz khusus diampu oleh guru atau pengampu yang sudah khatam bilhifdzi 30 juz (Hafidz dan hafidzah). Koordinator BTAQ dan tahfidz mengungkapkan bahwa:

Perekrutan pengampu BTAQ dan tahfidz ini dilakukan atas persetujuan yayasan dan madrasah. Semua pengampu diambil dari para santri dari pondok sini karena kami beranggapan bahwa "Dari santri untuk santri oleh santri". Jadi para santri di sini juga ikut andil dalam mengampu BTAQ dan tahfidz di sini. ${ }^{113}$

Selain materi pelajaran, untuk menunjang keberhasilan kegiatan BTAQ dan tahfidz ini tentu juga dibutuhkan guru pengampu khusus dalam bidang tahfidz Al-Qur'an. Guru pengampu sangat diperlukan dalam membimbing, mengarahkan, dan menyimak hafalan-hafalan Al-Qur'an siswa. Kemampuan guru pengampu sangatlah mempengaruhi keberhasilan dalam proses hafalan Al-Qur'an siswa. Oleh karena itu sebelum membimbing siswa, ketua tim BTAQ dan tahfidz melakukan koordinasi dan memberikan pengarahan kepada para pengampu terkait pengelolaan kelas, metode pembelajaran, standar penilaian, dan sebagainya.

Dalam pembiasaan yang diterapkan oleh pihak MI Wahid Hasyim Yogyakarta, siswa

113 Hasil wawancara dengan Ibu Hikmah Maslahah, selaku koordinator 1 BTAQ dan tahfidz MI Wahid Hasyim Yogyakarta pada hari Kamis, 9 Maret 2017 pukul 10.15 WIB 
senantiasa diajak untuk melakukan kebaikan terhadap dirinya sendiri maupun kepada orang lain, misalnya:

\section{a. Pembiasaan Berjabat Tangan Dan Mengucapkan Salam \\ Di lingkungan MI Wahid Wasyim} Yogyakarta yang berada pada satu lingkungan dengan Pondok Pesantren Wahid Hasyim, menerapkan pembiasaan berjabat tangan dan mengucapkan salam. Yaitu, pada saat memasuki pintu gerbang madrasah. Di antara sesama warga madrasah (guru, karyawan, dan para siswa) senantiasa dibiasakan "3S", yaitu senyum, sapa dan salam apabila bertemu. Kebiasaan tersebut bertujuan agar antara sesama warga madrasah terjalin hubungan yang harmonis dan dinamis. Berjabat tangan dilakukan antara perempuan dengan perempuan dan laki-laki dengan laki-laki. Akan tetapi, untuk para siswa berjabat tangan dengan guru laki-laki maupun perempuan sebagai sikap penghormatan terhadap bapak atau ibu guru.

Kegiatan ini rutin dilakukan setiap pagi hari, ketika akan memasuki lingkungan madrasah. Tepatnya di gerbang utama madrasah dan gerbang belakang madrasah. Setiap guru dan karyawan yang datang lebih awal diwajibkan untuk menyambut para siswa kurang lebih pada pukul 06.25 WIB. Biasanya bapak atau ibu guru sudah siap berdiri di sisi dalam gerbang madrasah untuk menyambut kedatangan para siswa. Selain itu, apabila ada pengumuman yang dibuat oleh pihak madrasah maka guru dan karyawan akan memberitahu dan mengingatkan kembali kepada para orang tua yang sedang mengantar anaknya ke madrasah. ${ }^{114}$

Dalam kaitannya dengan pembiasaan salam ini, guru senantiasa memberikan contoh kepada siswa. Saat siswa bertemu dengan guru dan belum mendahului salam, maka guru akan menyapa siswa dengan senyum dan salam terlebih dahulu sembari berjabat tangan. ${ }^{115}$

Saling berjabat tangan dan mengucapkan salam juga dilakukan ketika para siswa hendak pulang dari madrasah. Seusai kegiatan pembiaaan BTAQ dan Tahfidz yang dilaksanakan di serambi masjid, para siswa pun segera duduk membentuk barisan sesuai dengan kelas masing-masing. Bapak dan ibu guru yang mengajar akan berdiri dan membentuk barisan juga. Setelah itu para siswa berjabat tangan dengan bapak ibu guru sesuai dengan kelas yang terpilih lebih dahulu.

Kegiatan berjabat tangan tersebut merupakan program pembiasaan yang diterapkan oleh pihak madrasah guna membentuk lingkungan madrasah yang kondusif, agamis, kekeluargaan, keakraban, dan kehangatan dengan mengajarkan nilainilai penghargaan terhadap orang lain, disiplin dan penuh rasa tanggung jawab. Dari kegiatan tersebut, para siswa menjadi terbiasa untuk menyapa dan berjabat tangan serta mengucapkan kalimat salam baik dengan teman-teman sebaya mereka, para bapak atau ibu guru, karyawan atau dengan

114 Hasil observasi pembiasaan berjabat tangan dan mengucapkan salam di gerbang MI Wahid Hasyim Yogyakarta pada hari Kamis, 19 Januari 2017 pukul 06.30 WIB

115 Hasil wawancara dengan Bapak Aris Munandar, S.H.I,. M.Pd.I selaku kepala madrasah MI Wahid Hasyim Yogyakarta pada hari Kamis, 19 Januari 2017 pukul 09.05 WIB 
orang lain. Selain itu pembiasaan berjabat tangan ini juga terbawa dalam kehidupan sehari-hari para siswa di rumah.

b. Pembiasaan Membaca Do'a Sebelum Pelajaran Dimulai Dan Saat Pelajaran Pada Jam Terakhir Telah Selesai

Kegiatan membaca do'a bersama sebelum pelajaran pertama dimulai dan sesudah jam pelajaran terakhir selesai merupakan pembiasaan yang diterapkan oleh pihak madrasah bagi para siswanya. Pembiasaan inibertujuan untuk menanamkan rasa keimanan dan ketaqwaan bagi para siswa.

Kegiatan berdo'a dipimpin oleh setiap ketua kelas dari masing-masing kelas. Setelah bel tanda masuk berbunyi, para siswa segera memasuki ruangan kelas masing-masing. Terkadang sembari menunggu kedatangan bapak atau ibu guru, para siswa bersendagurau dan membuat gaduh di kelas. Bahkan ada beberapa siswa yang masih berkeliaran di luar ruang kelas. Para bapak atau ibu guru masuk ke dalam ruang kelas maksimal 5 menit dari bel tanda berbunyi. Guru masuk ke dalam ruang kelas kemudian mengucapkan kalimat salam kepada para siswa dan dibalas oleh para siswa. Setelah bapak atau ibu guru duduk di kursi guru, ketua kelas segera memimpin do'a dengan mengucapkan kalimat perintah "berdo'a mulai", yang segera diikuti bacaan do'a oleh seluruh siswa dan bapak atau ibu guru. Adapun bacaan doa'a yang diucapkan adalah sebagai berikut:

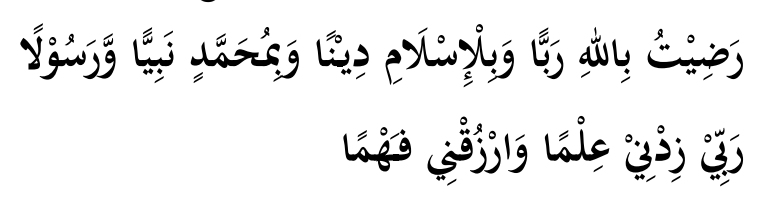

"Kami ridho Allah SWT sebagai Tuhanku,
Islam sebagai agamaku, dan Nabi Muhammad sebagai Nabi dan Rasul, Ya Allah, tambahkanlah kepada ilmu dan berikanlah aku pengertian yang baik". ${ }^{116}$

Berdasarkan hasil observasi yang peneliti lakukan, pembiasaan berdo'a sebelum pelajaran pada jam pertama ini telah dilaksanakan dengan cukup khusu' meskipun ada beberapa siswa yang tidak serius dalam melakukan kegiatan ini. Ketika do'a berlangsung posisi para siswa berada di tempat duduk masing-masing, tangan dilipat di atas meja kemudian do'a dimulai secara bersama-sama. Setelah do'a selesai kemudian mereka mengucapkan kalimat "amin yaa robbal 'alamin", kemudian dilanjutkan dengan kegiatan BTAQ dan tahfidz. ${ }^{117}$

Demikian juga saat jam pelajaran terakhir telah usai, kemudian bapak atau ibu guru memberikan salam penutup dan para siswa segera ke luar kelas menuju ke masjid yang berada di lingkungan Pondok Pesantren Wahid Hasyim untuk mengikuti kegiatan sholat Dhuhur berjama'ah dilanjutkan dengan kegiatan BTAQ dan tahfidz. Setelah kegiatan tersebut selesai bapak atau ibu guru mengkoordinasikan para siswa agar duduk di serambi masjid sesuai dengan kelas masing-masing secara tertib dan rapi. Kemudian salah satu bapak atau ibu guru memimpin bacaan sholawat di depan para siswa. Berikut adalah doa sesudah belajar yang dibaca bersama-sama:

116 http://bacaandoa.com/bacaan-doa-sebelumbelajar-doa-sesudah-belajar/, diunduh pada hari Sabtu, 11 Maret 2017 pukul 20.10 WIB

117 Hasil observasi pembiasaan membaca do'a di Kelas III MI Wahid Hasyim Yogyakarta pada hari Kamis, 19 Januari 2017 pukul 07.05 WIB 


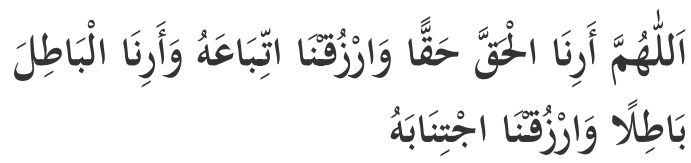

"Ya Alloh Tunjukkanlah kepada kami kebenaran sehinggga kami dapat mengikutinya Dan tunjukkanlah kepada kami kejelekan sehingga kami dapat menjauhinya." 118

Menurut hasil observasi yang peneliti lakukan ketika kegiatan ini berlangsung masih ada beberapa siswa yang bersenda gurau. Bapak atau ibu guru pun memilih siswa yang yang bersenda gurau tersebut untuk maju ke depan dan memimpin bacaan sholawat serta do'a yang diikuti oleh semua siswa. Kemudian bapak atau ibu guru yang memimpin kegiatan ini memilih kelas mana yang paling tertib dan rapi untuk berjabat tangan terlebih dahulu dengan para bapak atau ibu guru serta dilanjutkan pulang ke rumah masing-masing.

Pembiasaan berdo'a ini bertujuan untuk menanamkan rasa keimanan dan ketaqwaan bagi para siswa sebagai wujud pelaksanaan pembinaan akhlak yang harus dilakukan seorang hamba terhadap khaliknya, yaitu hanya menyembah dan memohon pertolongan kepada Allah SWT.

c. Pembiasaan Membaca Sholawat

MI Wahid Hasyim adalah salah satu madrasah di bawah naungan Yayasan Pondok Pesantren Wahid Hasyim Yogyakarta. Para siswa tidak hanya dibina mengenai ilmu-ilmu dunia saja akan tetapi juga dibina mengenai ilmu-ilmu keagamaan,

118 http://www.doamuslim.com/doa-setelah-belajarl, diunduh pada hari Sabtu, 11 Maret 2017 pukul 21.46 WIB untuk bekal di akhirat nanti. Pembiasaan yang diterapkan oleh pihak yayasan serta madrasah adalah sering membaca sholawat, yaitu Sholawat Syifa Tibbil Qulub.

Pembacaan sholawat ini ketika para siswa sedang melaksanakan kegiatan sholat Dhuha dan sholat Dhuhur berjamaah, serta saat berjabat tangan dengan bapak dan ibu guru ketika selesai kegiatan BTAQ dan tahfidz di siang hari. ${ }^{119}$ Tidak hanya para siswa yang membaca sholawat ini, bapak dan ibu serta karyawan yang sedang mengikuti kegiatan tersebut juga diwajibkan untuk membaca sholawat. Berikut adalah bacan Sholawat Syifa Tibbil Qulub:

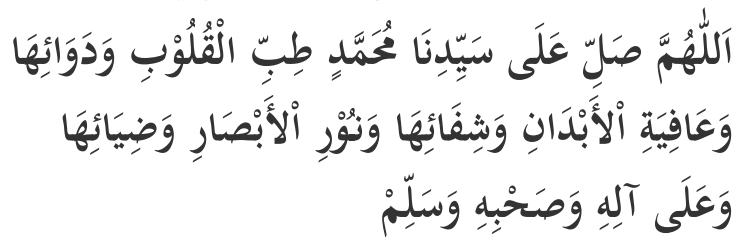

"Ya Allah, limpahkanlah rahmat yang disertai ta'dzim kepada Nabi Muhammad sebagai penyembuh semua hati dan menjadi obatnya, keafiatan badan dan kesembuhannya, cahaya segala penglihatan dan menjadi sinarnya. Dan semoga terlimpahkan pula shalawat dan salam kepada keluarga dan sahabat beliau." 120

Sholawat Syifa Tibbil Qulub
dikhususkan untuk mengobati dan
menyembuhkan berbagai macam penyakit,
baik penyakit dhohir atau badaniyah maupun
batin atau hati. Beberapa fadhilah Sholawat

119 Hasil observasi pembiasaan membaca sholawat di Masjid Jami' Gaten pada hari Selasa, 24 Januari 2017 pukul 13.30 WIB

120 https://muslimfiqih.blogspot.co.id/2016/02/bacaansholawat-tibbil-qulub-syifa-khasiat. html, diunduh pada hari Sabtu, 13 Maret 2017 pukul 10.21 WIB 
Tibbil Qulub adalah mengobati tubuh dari beberapa penyakit (memberikan kesehatan), menjadikan beban hati dan badan serta pikiran semakin ringan, menyembuhkan dan mengobati hati dari sifat tercela dan kegundahan atau waswas, serta memberi cahaya dan sinar bagi mata hati dan sebagainya.

Pada dasarnya bersholawat kepada Rasulullah memiliki banyak sekali khasiat yang tidak terhitung oleh akal manusia dan salah satu ganjaran terbesar sholawat adalah Allah SWT membalasnya dengan 10 kali sholawat yang berupa rahmat yang langsung mendatangi kita. Oleh karena itu, pihak madrasah membina para siswanya agar senantiasa memperbanyak sholawat. Selalu sempatkan bershalawat dalam semua aktivitas sehari-hari. Agar semua yang dilakukan selalu dirahmati Allah SWT dan senantiasa menjadi berkah.

\section{d. Pembiasaan BTAQ dan Tahfidz}

Kegiatan BTAQ dan tahfidz merupakan pembiasaan wajib yang diterapkan oleh pihak madrasah bagi para siswanya. Kegiatan ini diikuti oleh seluruh kelas dan dilaksanakan setelah kegiatan sholat Dhuha berjama'ah sebelum pelajaran dimulai dan setelah kegiatan sholat Dhuhur berjamaah. Dalam pelaksanaan kegiatan BTAQ dan tahfidz pada pagi hari berlangsung kurang lebih 35 menit. Pada hari Senin berlangsung pada pukul 08.05-08.40 WIB, sedangkan pada hari Selasa hingga Jum'at berlangsung BTAQ pada pukul 07.30-08.05 WIB dan untuk tahfidz pada pukul 08.05-08.40 WIB. Pada siang hari pelaksanaan BTAQ dan tahfidz berlangsung kurang lebih 30 menit yaitu pada pukul 13.30-14.00 WIB atau setelah kegiatan sholat Dhuhur berjamaah. ${ }^{121}$ Jadi begini mbak, metode hafalan di madrasah kami adalah dengan cara sorogan mandiri. Setiap kelas dibagi menjadi beberapa kelompok sesuai dengan kemampuan/ kecepatan menghafal siswa. Setiap kelas terdapat minimal 3 pengampu. Dengan setiap pengampu mengampu sekitar 8 hingga 10 siswa. Setiap siswa itu memiliki buku hijau atau buku harian yang di dalamnya berisi catatan hafalan serta baca Al-Qur'an. Untuk penilaian yang kuantitatif masuk ke penilaian UAS kalau yang kualitatif mereka akan dipantau terus baca AlQur'an dan hafalannya. ${ }^{122}$

Kegiatan BTA dan Tahfidz diawali dengan klasikal bersama Juz 'Amma, kemudian menghadap kepada pengampu sacara bergantian satu persatu. Sambil menunggu giliran, siswa menulis (imla) yang wajib dinilai oleh pengampu. Dalam satu kali tatap muka, siswa membaca Iqra' atau Al-Qur'an yang disima' pengampu (binnadzri), dan hafalan dengan setoran hafalan minimal 2-4 ayat setiap hari. Dalam seminggu sekali untuk siswa kelas atas IV, V, dan VI diadakan pendalaman makna (tarjim) agar siswa mengetahui makna suratan atau ayat yang selama ini dihafalkan, sehingga hafalan tidak sekadar hafal, namun dapat mengetahui makna sehingga harapannya siswa dapat menerapkan dalam kehidupan sehari-hari. Setiap siswa memiliki buku harian BTAQ dan tahfidz untuk mengetahui perkembangan anak tersebut yang dibawa

121 Hasil dokumentasi MI Wahid Hasyim Yogyakarta

122 Hasil wawancara dengan Ibu Hikmah Maslahah, selaku koordinator 1 BTAQ dan tahfidz MI Wahid Hasyim Yogyakarta pada hari Kamis, 9 Maret 2017 pukul 10.15 WIB 
oleh pengampu masing-masing.

Dalam kegiatan BTAQ dan tahfidz setiap kelas memiliki target yang berbedabeda. Selain itu MI Wahid Hasyim juga membentuk kelas tahfidz khusus, yang di dalamnya terdapat siswa dengan kemampuan menghafal lebih cepat daripada siswa yang lain. Kegiatan kelas tahfidz khusus ini dilaksanakan pada pagi hari, yaitu ketika kegiatan BTAQ dan tahfidz sedang berlangsung. Adapun wawancara yang peneliti lakukan mengenai kelas tahfidz khusus ini, sebagai berikut:

Setiap kelas tentunya memiliki anak dengan kemampuan menghafal lebih cepat. Kelas ini hanya diikuti oleh kelas II-VI saja. Pada semester ini terdapat 32 siswa dan 3 pengampu. Satu pengampu memiliki 10-11 siswa. Biasanya kami melaksanakan kegiatan ini dengan berkumpul di serambi masjid. Alhamdulillah, kelas ini sudah berjalan dengan efektif. ${ }^{123}$

e. Pembiasaan Sholat Dhuha Berjamaah

Kegiatan sholat Dhuha berjamaah di MI Wahid Hasyim Yogyakarta ini dimaksudkan agar para siswa terbiasa untuk melaksanakan amalan-amalan dan ibadah yang sunnah hukumnya. Selain itu juga untuk mendidik para siswa agar senantiasa mendekatkan diri kepada Allah SWT dalam segala aktivitas kehidupannya dengan cara memperbanyak amalan sunnah.

Sholat Dhuha ini dilaksanakan secara bersama-sama yaitu oleh semua siswa mulai dari kelas I - VI dan para bapak ibu guru. Pembiasaan ini dilak-

123 Hasil wawancara dengan Ibu Hikmah Maslahah, selaku koordinator 1 BTAQ dan tahfidz MI Wahid Hasyim Yogyakarta pada hari Kamis, 9 Maret 2017 pukul 10.15 WIB sanakan sebelum kegiatan BTAQ dan tahfidz yaitu setelah tanda bel pertama berbunyi. Para siswa yang baru datang pun akan bergegas menuju masjid. Bagi siswa perempuan diwajibkan membawa mukena sendiri-sendiri. Masjid ini sebenarnya bukan milik pondok tetapi milik Kampung Gaten, karena letaknya berada di lingkungan pondok maka masjid ini juga dimanfaatkan untuk warga madrasah dan warga pondok. Jadi intinya pihak pondok bekerjasama dengan pihak kampung ini. ${ }^{124}$

Kegiatan sholat Dhuha secara berjamaah ini dilakukan pada hari Senin pukul 07.3008.05 WIB setelah upacara selesai dan hari Selasa hingga hari Jum'at pukul 07.00-07.30 WIB. Setelah bel tanda masuk berbunyi para siswa segera menuju ke masjid untuk melaksanakan sholat Dhuha. Masjid yang dipergunakan untuk beribadah ini terletak di utara madrasah yang masih berada di satu lingkungan Pondok Pesantren Wahid Hasyim. Sambil menunggu para siswa lainnya yang masih mengambil air wudhu, mereka duduk dan membentuk shaf sholat di dalam masjid. Letak tempat wudhu untuk laki-laki dan perempuan terpisah, yaitu tempat wudhu untuk perempuan berada di selatan masjid dan tempat wudhu untuk laki-laki berada di utara masjid. Untuk jamaah laki-laki berada di dalam masjid, sedangkan jamaah perempuan berada di belakang jamaah laki-laki serta di serambi masjid. Pada setiap kegiatan sholat Dhuha ini biasanya didampingi oleh 2 orang guru untuk jamaah laki-laki dan 2 orang guru untuk jamaah perempuan yang bertugas

124 Hasil wawancara dengan Bapak Deni Endika Suteja selaku koordinator sholat di MI Wahid Hasyim Yogyakarta pada hari Kamis, 19 Januari 2017 pukul 10.30 WIB 
sebagai pengawas demi kelancaran kegiatan ini. Bapak atau ibu guru bertugas untuk mengawasi para siswa dari mereka keluar dari dalam kelas, saat mereka mengambil air wudhu sampai pelaksanaan sholat telah selesai dilaksanakan.

Sholat Dhuha ini dilaksanakan 2 raka'at, akan tetapi sebelum melaksanakannya para siswa dan para guru melakukan praktik sholat Dhuha dengan melafalkan bacaan-bacaan sholat Dhuha secara bersama-sama dengan suara yang keras. ${ }^{125}$ Hal ini dimaksudkan agar saat para siswa melaksanakan kegiatan sholat Dhuha dapat melafalkan bacaanbacaan sholat Dhuha dengan baik dan lancar di dalam hati. Setelah praktik sholat Dhuha selesai, segera imam menyuruh para siswa untuk membentuk shaf sholat dengan rapi dan rapat.

Setelah semua shaf sholat rapi dan dirapatkan, imam segera melakukan Takbiratul Ihram, dan memimpin jalannya sholat sampai selesai sebanyak dua rakaat. Ketika sholat selesai imam yang bertugas menjadi pemimpin sholat juga bertugas untuk memimpin do'a setelah sholat Dhuha. Pertama-tama do'a dibaca imam dengan suara yang cukup keras secara terpotongpotong dari rangkaian do'a yang ada, setelah itu ditirukan oleh para siswa semuanya. Kemudian para siswa membaca Sholawat Syifa Tibbil Qulub secara bersama-sama dengan suara yang keras. Adapun do'a setelah sholat Dhuha yang dibaca sebagai berikut:

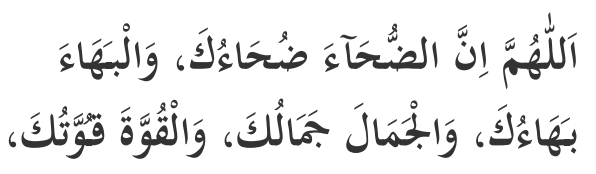

125 Hasil observasi pembiasaan sholat Dhuha berjamaah di Masjid Jami' Gaten pada hari Selasa, 24 Januari 2017 pukul 07.10 WIB

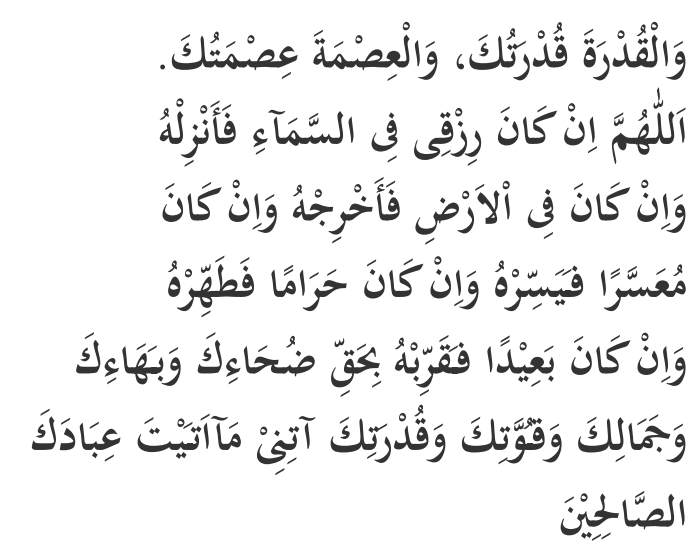

"Wahai Tuhanku, sesungguhnya waktu dhuha adalah waktu dhuha$\mathrm{Mu}$, keagungan adalah keagunan$\mathrm{Mu}$, keindahan adalah keindahan$M u$, kekuatan adalah kekuatan-Mu, penjagaan adalah penjagaan-Mu, Wahai Tuhanku, apabila rezekiku berada di atas langit maka turunkanlah, apabila berada di dalam bumi maka keluarkanlah, apabila sukar mudahkanlah, apabila haram sucikanlah, apabila jauh dekatkanlah dengan kebenaran dhuhaMu, kekuasaan-Mu (Wahai Tuhanku), datangkanlah padaku apa yang Engkau datangkan kepada hamba-hambaMu yang soleh." "126

Setelah semua rangkaian kegiatan ini selesai dilaksanakan, kemudian para siswa segera keluar menuju serambi masjid untuk berjabat tangan dengan bapak dan ibu guru serta segera menuju ke ruang kelas masingmasing untuk memulai kegiatan belajar.

f. Pembiasaan Sholat Dhuhur Berjamaah

Sholat Dhuhur berjamaah merupakan salah satu kegiatan pembiasaan yang diterapkan oleh pihak madrasah kepada para siswanya. Kegiatan ini selain diwajibkan kepada para siswa juga diikuti oleh sebagian besar bapak dan ibu guru yang kebetulan tidak

126 http://www.doamuslim.com/doa-setelahsholat-dhuhal ,diunduh pada hari Sabtu, 13 Maret 2017 pukul 10.21 WIB 
sedang berhalangan untuk menjalankannya.

Waktu pelaksanaan kegiatan pembiasaan ini kurang lebih pukul 13.00 WIB sampai dengan pukul 13.30 WIB. Segera setelah bel tanda jam pelajaran terakhir berbunyi para siswa dan guru menuju ke masjid untuk mengambil air wudhu. Salah satu bapak guru yang menjadi imam pun segera mengumandangkan adzan dhuhur juga sekaligus mengumandangkan iqomah sebagai pertanda pelaksanaan sholat Dhuhur secara berjamaah akan segera dimulai. Selang waktu antara adzan dan waktu iqomah di madrasah ini kurang lebih 10 menit untuk memberikan kesempatan bagi para siswa.

\section{KESIMPULAN}

Perencanaan pelaksanaan pembinaan akhlak siswa di MI Wahid Hasyim Yogyakarta disusun dengan merumuskan tujuan dan target, merekrut pengampu, menyediakan fasilitas yang memadai, memaksimalkan dana dan evaluasi kegiatan. Implementasi pembinaan akhlak siswa melalui metode pembiasaan yang diterapkan oleh MI Wahid Hasyim Yogyakarta ini meliputi: pembiasaan berjabat tangan dan mengucapkan salam, pembiasaan membaca do'a sebelum pelajaran dimulai dan saat pelajaran pada jam terakhir telah selesai, pembiasaan membaca sholawat, pembiasaan BTAQ dan tahfidz, pembiasaan sholat Dhuha berjamaah, pembiasaan sholat Dhuhur berjamaah, pembiasaan kegiatan infak setiap hari Jum'at, pembiasaan saling menolong, pembiasaan menjaga kebersihan lingkungan. Pembinaan akhlak siswa melalui metode pembiasaan berupa kegiatan pembiasaan harian yang ditempuh oleh MI Wahid hasyim Yogyakarta tersebut belum berjalan secara optimal, karena adanya beberapa faktor. Faktorfaktor tersebut meliputi: a) Faktor pendukung, meliputi manajemen waktu, minat dan motivasi siswa, fasilitas yang memadai. b) Faktor penghambat, meliputi kurangnya motivasi dan minat siswa, bimbingan guru dan pengampu yang kurang maksimal, kurangnya dukungan orang tua.

\section{DAFTAR PUSTAKA}

Anggoro, Rino. Pembiasaan Perilaku Keagamaan Pada Anak di SDIT Al-Muti'in Maguwo Banguntapan Bantul. Yogyakarta: Fakultas Tarbiyah dan Keguruan UIN Sunan Kalijaga Yogyakarta, 2008.

Arikunto, Suharsimi. Prosedur Penelitian: Suatu Pendekatan Praktek. Jakarta: Rineka Cipta, 1998.

Aziz, Erwati. Prinsip-prinsip Pendidikan Islam. Solo: Tiga Serangkai Pustaka, 2003.

Azra, Azyumardi, dkk. Pendidikan Agama Islam Pada Perguruan Tinggi Umum. Direktorat PTAI: Direktorat Jendral Kelembagaan Agama Islam Departemen Agama RI, 2002.

Bakar Jabir El-Jazari, Abu. Pola Hidup Muslim (Minhajul Muslimin) Etika. Penerjemah: Achmad Djatnika dan Achmad Sumpeno. Bandung: PT Remaja Rosdakarya, 1993.

Bakry, Oemar. Akhlak Muslim. Bandung: Angkasa, 1986.

Baradza, Umar. Bimbingan Akhlak bagi Putra-putri Anda-2. Surabaya: Pustaka Progressif, 1992.

D. Marimba, Ahmad. Pengantar Filsafat Pendidikan Islam. Bandung: Al-Ma'rif, 
1974.

Daradjat, Zakiah. Peranan Agama dalam Kesehatan Mental. Jakarta: Gunung Agung, 1989.

Daradjat, Zakiah. Ilmu Jiwa Agama. Jakarta: PT. Bulan Bintang, 1970.

Daud, Ali Muhammad. Pendidikan Agama Islam. Jakarta: PT. Raja Grafindo Persada, 1998.

Departemen Agama RI. Al-Qur'an dan Terjemahannya. Semarang: CV. Toha Putra, 1989.

Departemen Pendidikan dan Nasional. Kamus Besar Bahasa Indonesia. Jakarta: Jakarta Press, 1995.

Djatnika, Rachmat. Sistem Ethika Islami(Akhlak Mulia). Jakarta: Pustaka Pandjimas, 1996.

Djiwandono, Sri Esti Wuryani. Psikologi Pendidikan. Jakarta: PT. Grasindo, 2008.

Erna, Siti Nur'aina. Pembinaan Akhlak Terhadap Siswa Madrasah Tsanawiyah Program Thakasus Pondok Pesantren Wahid Hasyim Yogyakarta. Yogyakarta: Fakultas Tarbiyah UIN Sunan Kalijaga Yogyakarta, 2009.

Esti Wuryani Djiwandono, Sri. Psikologi Pendidikan. Jakarta: PT. Grasindo, 2002.

Harahap, Nasrun dan Jamil Abu Bakar. Pengantar Studi Kurikulum: Jakarta: Pepara, 1981.

Hasan, Maimunah. Membentuk Pribadi Muslim. Yogyakarta: Pustaka Nabawi, 2002.

Helmi, Masdar. Peranan Dakwah Islam dalam Pembinaan Ummat. Semarang: Lemb. Panel dan Pelatihan, 1971.
Moleong, Lexy. J. Metodologi Penelitian Kualitatif. Bandung: Remaja Rosada Karya, 2002.

Mulyasa, E. Manajemen Pendidikan Karakter. Jakarta: Bumi Aksara, 2011.

Mustofa, Ahmad. Akhlak Tasawuf. Bandung: CV. Pustaka Setia, 1997.

Nata, Abuddin. Filsafat Pendidikan Islam I. Jakarta: Logos Wacana Ilmu, 1997.

Noer Aly, Hery. Ilmu Pendidikan Islam. Jakarta: Logos Wacana Ilmu, 1993.

Suwito, Umar. Character Building (Bagaimana Mendidik Anak Berkarakter?). Yogyakarta: Tiara Wacana, 2008.

Syah, Muhibbin. Psikologi Pendidikan Suatu Pendekatan Baru. Bandung: Remaja Rosdakarya, 1995.

Undang-undang Sisdiknas. Jakarta: Sinar Grafika, 2003.

Zainuddin. Seluk-Beluk Pendidikan Al-Ghazali. Jakarta: Bumi Aksara, 1991. 
